\title{
Bible subversion: An ideology critique of the manner and motif behind the use of scriptures by politicians
}

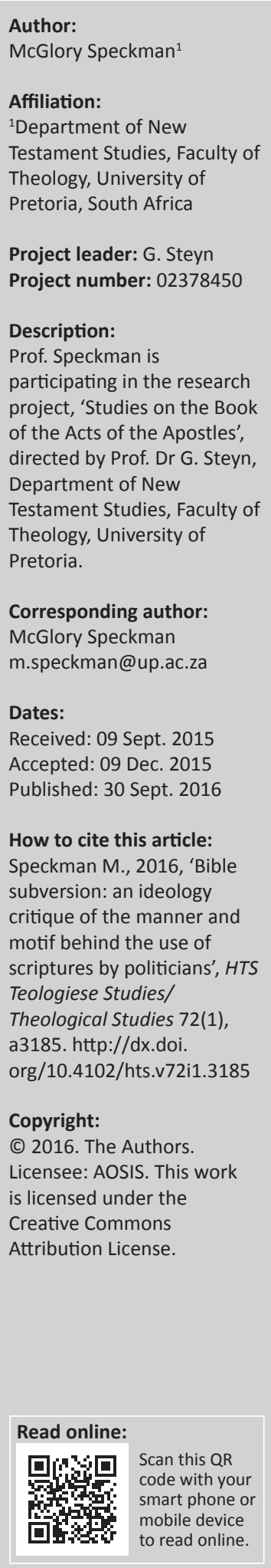

The use of biblical texts by politicians in recent years has led to a proliferation of critical publications by biblical scholars. Some focus on reconstructing the rhetoric itself, others on analysing the historical context while others still, on why and how the scriptures are used. A lack of an ideology critique dimension makes these analyses appear to be naïve to the extent that they miss the element of the subversion of scriptures by politicians who use them. Biblical texts on the whole, are a product of an anti-establishment culture and where they are appropriated by the establishment, a hermeneutic of suspicion should apply. This paper utilises ideology critique as it reflects on the manner and motif behind the use of scriptures by politicians. It concludes that scriptures are subverted in order to force them to serve ideological ends.

\section{Introduction}

The use of the scriptures by politicians in recent years has led to the publication of several critical publications by biblical scholars. ${ }^{1}$ Some focus on reconstructing the context of the rhetoric itself (Berlinerblau 2008), others on analysing religious implications (West 2012) while others still, on why and how (subversive element) the scriptures are being used (Benedix et al. 2009). The latter gets close to the point made in this article. However, a lack of an ideology critique dimension makes these analyses appear to be naïve to the extent that they miss the element of the subversion of scriptures for ideological purposes. Biblical texts on the whole, are a product of an antiestablishment culture although some have been co-opted by the ruling classes (Gottwald 2008; Punt 2006; Bauckham 1989; Wittenberg 1993 cf esp. Mosala's historical materialism approach to Old Testament texts 1989). Therefore, a subversion of the text in this context refers, not to the transfer of power to the underdog (Benedix et al. 2009:4-5) but to its blunting by the ruling classes so as to render it the opposite of an empowering tool. Hence the need to apply a hermeneutic of suspicion. ${ }^{2}$

This article attempts an ideology critique of the manner in which the texts are used by politicians in their interaction with the public and the motifs behind that. A question raised by Benedix (2009:2) pertaining to the kind of biblical texts that seem to resonate with the aims of politicians is inevitable. This alone, hints at the power of rhetoric or skilled use of words to rewrite (Twomey 2010:12) or subvert the meaning of popular texts. Rewriting is one of the strategies used to subvert a text in that it is a 'renarrativisation' (Twomey 2009:12) of an earlier text which renders it a 'look alike'. As Twomey warns, '... biblical rewriting is always subversive, ironic, or deconstructive- whatever the author's intentions' (Twomey 2009:13). By this he means that it is never neutral and without 'ideological' significance (Twomey 2009:13). The question is 'why certain texts and not the others?' Unlike biblical scholars, politicians are not under obligation to use the scriptures in addressing audiences. They make use of popular texts and symbolism which are often employed by the faithful in their daily struggles. This is made possible by the vulnerability or malleability of the biblical text, a perennial challenge for global biblical scholars. ${ }^{3}$ I argue that, in the hands of politicians, scriptures almost invariably serve ideological ends which 1.The list includes inter alia the following: Baukham (1989), Draper (1992), Horsley (2008), Berlinerblau (2008), Benedix (2009), West (2010, 2012) and Gunda et al. (2012).

2.This is a Ricoeurian term that refers to the questioning of motifs behind a statement that would normally be accepted at face value. It has to be mentioned at the same time that sceptics are in fact, suspicious of some biblical texts because of their inherent violence and bias against the marginalised. Mosala (1989), in his materialist reading of the text attempts to get behind what he views as an appropriated text (West 1991) to its 'sharp', pre-canonical stage.

3.It is tempting to add: 'and the gullibility of the unsuspecting citizens'. However, the level of political consciousness among South Africans is relatively high. They question almost every statement made by politicians. Even the individual who initiated the conversation with West may have been one of the pessimists. 
manifest in the use of language and the tactic of legitimation (Zizek 1994:117) and that these often end up bolstering the system-whether good or bad.

It is for this reason that an endorsement of the use of scriptures by politicians is problematic. For example, the editors of a collection of essays on the Bible and Politics in Africa, Gunda and Kugler (2012) respond to West's citing in their volume (2012:112) of a remark about Zuma's knowledge of the Bible with a comment to the effect that the remark is 'indicative of the ordinary Africans's appreciation of the use of the Bible by politicians across African states today'. This is debatable for two reasons: firstly, symbolism from the scriptures has played a different role during the African underdogs' struggles against colonialism. They did not serve as political and ideological arsenal. ${ }^{4}$ Secondly, biblical scholars will not have learnt any lessons on 'how not to use the scriptures' - from the destructive use of the Bible in the debate on slavery in the United States of America (18th and 19th centuries) or the development of the 'Aryan race' ideology in Nazi Germany (1948 [1918]) or the apartheid ideology in South Africa (1994 [1943]) if they allowed politicians a free reign over the Bible and religion. Admittedly, no one should have a monopoly over the interpretation of the text. However, a constant check which involves, inter alia, interrogating the utterances, should convey the message that biblical interpretation is also a site of struggle (West 2008). The international situation will be briefly surveyed, followed by a focus on South African scenarios.

The first part of this article consists of a brief outline of the nature and extent of the problem, followed by a critical appraisal of the scholarly views on the topic. This is followed, in the second part, by a discussion of ideology, then the vulnerability of the text. In the third part, different scenarios are discussed, focussing in particular on South African scenarios.

\section{The nature and extent of the problem}

The problem at hand is neither new (see anti-slavery movement) nor unique to South Africa (see Bush and Obama). It is a global phenomenon which cuts across religions (see Jihadists) ${ }^{5}$ and ages (see Cicero's use of religion) ${ }^{6}$ - hence international interest in the topic. The particular interest of this article is, however, on the use of Christian scriptures as this is the tradition within which I am working and writing.

\footnotetext{
4.In order to avoid digressing from the point about ideologiekritik, a full argument on 4. In order to avoid digressing from the point about ideologiekritik, a full argument on
the above will not be pursued in this article. The following summary should suffice: African Theology only came into the picture as colonialism was beginning to crumble (after the 1966 Ibadan summit), with a focus on theology and African culture. Black Theology in South Africa (late 1960s) reacted to the use of the scriptures to negate blackness and Black Theology sought to assert and affirm blackness (see Tutu's 1979 article on the relationship between African and Black theologies). Liberation Theology (mid-1970s) was a tool of theological activists, not politicians, used to mobilise the oppressed against their oppression. The statement: 'seek ye first the political kingdom ...' which is associated with Nkrumah (1957), sounds more like a mocking or perversion of the biblical text than its manipulation. sounds more ike a mocking or per 'Lton Equal of Exodus but there is no 'Ldication in it of Luthuli claiming to be
}

5.See the use of Quran verses.

6.Virgil, Aenaid 1.278-279. Cicero (De officiis 2.26-27) claimed that Rome was elected by the gods to rule 'without end'. He imagined himself presiding over it as God's son.
While Europe seems to have dealt with this issue in previous centuries and does not perceive it as a challenge in contemporary history (Kugler 2012:9), leaders of the present United States of America seem to have made the use of scriptures part of their tradition. We take a cursory look at the use of the Bible by George W. Bush (jnr), former president who claimed biblical inspiration for most of his actions and the current incumbent, Barrack Obama. In several media interviews during 2014 and 2015, Bush repeatedly claims to be a 'born again' Christian who reads the Bible daily throughout his terms as President of the United States of America. The kind of religion he proclaimed though, and the constant claim about him taking his mandate from the Bible exposed him to mockery by his detractors. ${ }^{7}$ He had selected certain passages which favoured his view of a subjugating, non-questionable religion. Among the passages he used were Exodus, Revelation, etcetra. While there is little new in this as it could be expected of the Republican Party ideology, it is important not to lose sight of the fact that Bush has brought the use of the Bible back to the public sphere.

Barrack Obama's use of the scriptures is largely based on the utterances he made during his inaugural address as the President of the United States of America (Benedix 2009). During his inaugural speech, he outlined some scriptural verses as a basis for his intention to correct what had gone wrong during the presidency of his predecessor, George Bush (Bendix 2009:1). In 2014, he used Deuteronomy 10:19 and Leviticus 19:34 as a basis for his executive decision to allow five million foreigners to be settled in the United States (Washington Post, November 2014). During the first quarter of 2015 he again used the scriptures as he tried to defend the Christian values against the utterances of ultra conservative Republican-aligned Christians. These have less to do with prosperity or religious propaganda and more with a countermanding of propaganda from the conservatives and a defence of what he understood to be Christian values. The only thing that brings him close to his predecessors, including Bush and Jefferson (who incidentally sought to portray America as the New Israel- cf. Horsley 2008:1-2) was the use of the common refrain, 'God bless the United States of America' (Benedix, 2009:1) which Maluleke (2002:325) traces back to a Siberian immigrant, Berlin. It is noteworthy that in some cases, Obama used exactly the same scriptural verses as used by George Bush to convey the opposite message. Prior to his election, he had used the scriptures in religious contexts while the New York Times reported for the first time in June 2006, on his speech on Faith and Politics. There are more (negative) articles written about Obama and the scriptures than there are from him about the scriptures.

The overt use of biblical verses for ideological purposes by African politicians has not been a common practice. Even the African National Congress of South Africa whose leadership had always included clergy did not deliberately analyse scriptural verses for the purpose. ${ }^{8}$ Part of the problem was a

7.See mocking questions about whether the war was sanctioned by God in a dream (see, e.g. 'The Bible and Iraq', USA Today, 26 April 2013).

8.See the above note on Albert Luthuli's (1962) biography. 
lack of expertise in biblical exegesis as the training of its clergy in its leadership, was informed by dualism while there was also religious plurality within its ranks. Kwame Nkrumah (1957) with his western education, is remembered for his appropriation of the verse: 'seek ye first the kingdom of God' (Mt. 6:33) to read: 'seek ye first the political kingdom' on the eve of the independence of Ghana. This line, which has since been frequently repeated by African leaders to elevate their political goals above religion might appear to be a rewriting but it sounds more like a mocking of western religion than a pursuit of an ideology. Even the African Theology which came into being less than a decade thereafter (1966), did not forge links with politics while it was preoccupied with developing inculturation tools. Black Theology which came into being towards the end of the decade (1969) and early 1970s was considered by its African Theology counterpart to be more political than religious while it argued that it only focused on the biblical theme of liberation.

It should be noted that these theologies which I regard as existential theologies with existential interpretations of the Bible reacted to the establishment's version of the scriptures whether for religio-cultural or political purposes. They neither represented nor legitimated the establishment. Instead, they sought to undermine what they regarded as an illegitimate use of the scriptures by an illegitimate state. It will become clear when the South African scenario is discussed, how these differed from the approaches under scrutiny. Moreover, these are theologies driven by theologians, not politicians although individual proponents may be sympathetic, even affiliated to political parties. The implication of African politicians in the use of scriptures is a later development which Vengeyi (2012:81-82) rightly or wrongly credits with the facilitation of pan-Africanism.

In the official South African context in particular, scriptures were used by politicians and their allies in theology and sociology departments ${ }^{9}$ in an unprecedented manner. Even the Euro-western slave-masters had not initially used the scriptures as their point of departure but in countering scripture-based arguments against the slave trade. As the records analysed by Loubser (1987) in his Apartheid Bible show, the Apartheid architects had an in-depth analysis of selected biblical texts which were obviously read with the view to justifying the racial ideology that was being mooted by the Nationalist Party. This interpretation was imposed on everyone under a constitution which purportedly promoted the Christian faith. More than just uttering occasional texts, theirs was to use the biblical texts as a blueprint for life and a foundation for the constitution they had used to withdraw from British rule in $1961^{10}$.

The selected scenarios (pre- and post-Apartheid) that are used to illustrate the point made about the behaviour of

\footnotetext{
9.See the publications of Geoff Cronje (1945-1948), a professor of Sociology at the University of Pretoria (cited in Welsh 2009). The 1947 article is particularly pointed as it alludes directly to 'justified racial segregation'.

10.31 May was set aside as a day of commemorating the historic step taken by the Nationalist Party in 1961.
}

politicians in the South African context represent two worlds that were once disparate or as far from each other as the East is from the West. In one world, texts are initially used as a foundation for the creation of a race that purports to have been chosen as the 'new Israel', its nurture and the protection of its incubator- the Apartheid state. Occasionally, they are used to demonise those regarded as dissidents. Some diehards still believe that God 'uprooted their ancestors from Europe to come and convert, then act as guardian of the natives' in South Africa (Welsh 2009:15). The other world is initially characterised by the use of the scriptures to persuade the nation to act ethically, especially in respect of corruption (West 2012). Later, the scriptures became a legitimating tool for the party and for individuals (Van Onselen 2014:3-18).

Beyond the initial phase of Apartheid philosophy, texts such as Romans 13:1-7 were used as a constant reminder of the authority of the state and unconditional submission to it, demanded. Of course, such texts also warned the would-be offender of the might of the state and the consequences of disobedience (Rm. 13:4). This played into the hands of a state whose ideology was being subverted and undermined by other forces inside and outside of South Africa. Regrettably, the understanding was literal ${ }^{11}$ as the state conveniently saw it as a conferment of unlimited powers on the state to do as they wished (Draper 1988). Clearly, biblical texts were seen by some as part of the arsenal of Apartheid ideologists. Hence the World Alliance of Reformed Churches declared Apartheid a heresy in 1982, three years before the publication of The Kairos Document.

There is an expression to the effect that 'if you leave the axe with which you have been hewing wood outside the house, the robber might pick it up and use it against you' (anonymous). As it happened in South Africa and elsewhere in the world, proponents of what I have referred to above as existential theologies used the same scriptures to refute the claims and pronouncements made by Apartheid theologians, stake their claims that God was on the side of the oppressed as well as mobilise Christians to resist an unjust system. Both sides claim to be interpreting from the perspectives of their horizons (Croatto 1983, 1987) ${ }^{12}$. The fundamental difference is that the Bible was in the hands of 'prophetic theologians', on the one end and of politicians, on the other. Hence disparity in their theologies. I will, for the purposes of this article, limit my discussion to the post-apartheid political figures, in particular, Thabo Mbeki and Jacob Zuma.

The above survey portrays a fluctuation from chauvinistic to ethical to coercive then subtle use of the scriptures. There appears to be an element of subversion. In my view, this is made possible by the vulnerability or malleability of the text and it begs a closer look at the motive from the perspective of a democratic context. For this reason, I make a brief detour to the explanation of the vulnerability of the text.

11. am consciously using the word 'literal' to refer to the assumption that the words meant exactly what they said, with no metaphorical connotations. This is different mean 'literary' which (see Gillingham 1998:171-176 for how and why this approach was introduced). 


\section{The vulnerability of the biblical text}

Many factors may account for the vulnerability of the text. It speaks to the nature of the Bible. Below, I only focus on three of these which, I believe, have a bearing on my analysis in this article.

Firstly, it should be borne in mind that biblical texts are creatures of the canonisation processes (Metzger 1987; McDonald 1995). As such, they are not infallible in respect of gaps and internal (and external) contradictions. These are gaps and contradictions pertaining to the nature of the God(s) portrayed in the text and the theology (-gies) conveyed by the texts. ${ }^{13}$ This leaves the meaning open-ended and the authority of the text at the discretion of the interpreting community (Suggit 1994:74-75). The up-side of this is that it makes the scriptures dynamic and accessible to all contexts and eras while the downside is that it opens it to abuse and/ or manipulation. Evidence of this is the manner in which the European colonisers who were accompanied by the Bible (see Isaak 1990) understood their mission to the southern tip of Africa. They viewed it in the same manner as the 'Apiru slaves understood their conquest of Canaan'. There is nothing wrong in terms of their contextualisation of the text although it raised several ethical questions, given the manner in which they acquired their new home.

Secondly, the accessibility of the text to everyone as a result of translations (Maluleke 2002), at different levels of the society is also both an advantage and a disadvantage. As various scholars have observed (e.g. West 1994), the biblical text is available even to those who are illiterate. It is usually either read out or narrated to them. Hence talk of the 'users' and 'interpreters' rather than the 'readers' of the Bible. There usually is distinguished between scientific and devotional (everyday) readers of the Bible. West (1994) refers to the same as 'privileged' and 'ordinary' readers, respectively. From a kerugmatic perspective, this is an advantage while from a scientific perspective, it is a disadvantage. It makes little sense to allow the so-called ordinary reader freedom to dabble with the text on the one hand, then deny them the right to express their point of view, on the other. The post-modernity framework with its objection to the 'universalisaton' or 'absolutisation' of the truth (see Lyotard 1984) has created room for various interpretations of reality to be accepted among valid expressions of truth. In this sense, both the ordinary reader's interpretation of the text and that of the privileged reader are viewed as being valid - a privilege which Mosala (1991) questions, labelling it as a 'confirmation of ordinary people's ignorance'.

Thirdly, the text reception theory (see Eagleton 1996) which is partly influenced by the above allows the reader the privilege to respond to what they find striking in the text. Scientifically, this is justifiable, if ordinary readers work under the eye of a

13.Mosala (1989) for example, dramatises the intra-canonical contradictions by portraying different Gods in his study of the Exodus. These are the god of the conqueror and the god of the conquered who convey diagonally opposed messages. The situation therefore causes one to ask 'which/whose god is it?' messages. The situation therefore causes
before accepting the account at face value. 'privileged reader'. While there should be 'limited degrees' of interpretation (Speckman 1995), there seems to be no (ideological) controls in place save the traditional orthodox framework (in some cases). If interpreters subscribe to a framework that favours racism, for example, they will find support in the text and there would be nothing unorthodox about the manner they understand it because it would reflect their interpretation of 'orthodoxy'. The role of the 'privileged reader' in such situations is usually to observe and assist in articulating what the 'interpreting community' sees in the text. This is not enough and I am not convinced that this was the intention of the Enlightenment.

Whether any of the above or an undisclosed agenda plays a role in the South African context will become clear below.

\section{Ideology, language and subversion}

We know from the insights of ideologiekritik that there is an inseparable link between ideology, language and subversion. This relationship will be explained in our brief but necessary outline of the theories of ideology and language. The attempt to analyse the interest and use of the scriptures by politicians will not make sense unless there is some appreciation of the anatomy of the concept 'ideology' and an understanding of the role played by language in furthering its aims. However, the ultimate focus of this section is on the aspect of subversion, the potential held by any language and/ or rhetoric. Given the analyses of Voloshinov (1973) and Althusser $(1984,2001)$, I have come to the conclusion that it is possible for the ruling class to subvert the programme of the working class masses and for former revolutionaries to turn into a (reactionary) ruling class.

It is no exaggeration to argue that modern understandings of ideology have their origins in the work of Marx and Engels, particularly, The German Ideology (Marx-Engels 1998 [1932]) and Capital vol. 1 (Marx 1999 [1867]). An entire scholarship, across the globe, developed - either in conversation with Marx or in rejection of his assertions (Engels features little in such debates). A particular aspect of their understanding of ideology (though Hall (1986) contends that this is not its essence) is the assertion that ideology is a reflection of a 'false consciousness' (see Gardiner 1992:6). They see it as a tool used by the ruling classes and their allies to blunt the national consciousness (see also Frey 1994:55). Marx himself defined the term as the 'system of ideas and representations which dominated the mind of a man or a social group' (Althusser 1984:32; Turner 1996:16; Hall 1986). Thus, he highlighted the dimension of a 'cognitive grasp of ideology on reality' which is often distorted through the influence of power and particular interests.

In his critique of Marx, Althusser (1984:2) places this in context. He points out that for Marx, the reproduction of the conditions which produced an ideology and the existing relations of production was the condition for its existence. Hence some falsification of reality (Turner 1996:15) by those who either want to protect labour or bourgeoisie interests, 
this disguising a conflict of group interests. In this way, Marx views ideology as a 'level which together with the economic and political levels, comprises a social formation' (McLennan et al. 1977:78). Althusser further highlights other elements of Marx's theory of ideology which include the following: 'state apparatus' which serves State power, 'ideological state apparatuses' which are a subtle form of enforcing ideology, relying on institutions such as family, church, school, prisons, etcetra (see Gramsci's Selection from Prison Notebooks 1971) and the use of language and legitimation as part of 'ideological state apparatuses'. Althusser (2001:96) also distinguishes between what he refers to as the Repressive State Apparatus and Ideological State Apparatuses. The former, he argues, relies predominantly on violence and secondarily, on ideology (2001:97). Education is a good example of an ideological apparatus that is utilised albeit ahead of family and religion. According to Althusser's (2001:98) analysis, no ideological group is immune to this temptation. Former revolutionaries also succumb to it because, as he correctly observes, 'no class can hold State power over a long period without at the same time exercising its hegemony over the State Ideological Apparatuses'. In support of this, he cites Lenin's use of education in favour of the Soviet proletariat who had seized power (2001:98-99).

Two important things among those highlighted by Althusser are of relevance to the discussion of this article. These are (1) language as a medium of communicating ideas and (2) legitimation which links the present to the past or the world of ancestors (Zizek 1993:117). The latter is invoked in an attempt to coerce people into accepting an idea that is being sold as having approval in a world 'beyond the present world' (see also Esler 1987). Language is utilised in conveying the sense that the present order is a fulfilment of the dreams of the previous generations (Zizek 1993:117). In support of this, Zizek asserts that in the former Soviet Union, those who criticised their (Russia's) efforts, were denounced as [traitors] who were making fun of, and betraying the dream of millions who suffered and risked their lives for 'what they are now realising'. In other words, the benefits testify to the 'dream of the ancestors come true' (Zizek 1993:117). By way of balancing this out with the first point, we outline the theory of language as developed by Voloshinov, one of Mikhail Bhaktin's disciples. ${ }^{14}$

As an introduction to the outline of Voloshinov's theory, Gardiner reminds the reader of Bakhtin's profound words, namely, that 'no word is found in a virginal state ... every word is "always-already" imbued with the evaluations and perceptions of others' (1992:7). Therefore, there is no innocence. Bakhtin also perceived of ideology along linguistic and semiotic lines, as in signifying practice which is produced within particular social contexts (1992:7). This speaks to the need to scrutinise every word uttered and against its context. In fact, Gardiner (1992:7) warns against the danger of looking at individual words rather than full statements and contexts against which the utterances take place.

14.The Bakhtin Circle was formed in the 1970 s to take his ideas forward. Voloshinov was part of the Circle.
With the above in mind, the main points of Voloshinov's theory as reconstructed by Gardiner (1992) from Voloshinov's 'Marxism and the Philosophy of Language' (1973 [1929]) are as follows:

1. A dialogic interaction between concrete communicative utterances, a phenomenon which involves all forms of semiosis and not just face-to-face speech-acts. Every utterance is produced by a concrete addressee and is oriented towards (real or presumed) addressees (1992:12)

2. As the socio-political order is internally and 'ecologically' stratified, so too is the organisation of verbal interaction. Individuals, being competent, knowledgeable agents, learn to tailor their utterances (with varying degrees of success) to conform to the demands of the immediate social situation or 'linguistic market', according to Pierre Bourdiou (1977) (cited on p.13)

3. Speakers from subordinate social groups are motivated to defer to the authoritative language. The oppressed can however, draw upon discernible symbolic and cultural resources which are at least, partly successful in resisting the dictates of the official language and its concomitant ideological forms.

4. Extra-verbal (contextual or situational) factors must also be taken into account in trying to understand the utterance's significance level (1992:15). It can only happen when language is taken in its full concrete scope. Thus, understanding is only possible in the dialogic space between active, responsive agents. In fact, 'true understanding is dialogic in nature'.

5. A word produced within a given speech complex possesses not only theme and meaning; it also expresses a particular value judgement or 'evaluative accent'.

6. The process of accentuation is a function of the evaluative context within which a particular utterance is enunciated. It links up with values, norms and beliefs. These are dynamic and polysemic, making meaning unstable (1992:15)

The above scheme offers both a warning and a key to unlocking or unmasking the hidden motif behind utterances. My view, in contrast to Voloshinov's, is that in general, some utterances may be innocent. However, their context and the manner in which words are arranged may reveal an ideology behind the words. This is where the 'evaluative context' must decide whether the ideology is subversive (i.e., counterproductive to their aspirations) or supportive (i.e., in aid of their aspirations). We have seen above that the former is possible and that State Apparatus may be used to enforce it. In instances where it is not possible to suppress, 'dialogic interaction' is applied as a way of 'marketing' the ideology. Dialogue however, implies a two-way process, some form of 'give and take'. This in most cases, is not what happens as the protagonist strives to win the audience over.

\section{Utterances, ideology and subversion}

Utilising the above-discussed ideas, I will now conduct an ideology critique of the biblical utterances of some politicians with the view to exposing the ideological motifs. They appear 
on the surface, as a 'dialogic interaction'. In fact, given the fact that they are addressed to certain audiences by highprofile politicians, there is no reason to see them otherwise. However, the audiences addressed see themselves as part of the 'first world', a developed or developing world which operates within the framework of western democracy. Therefore, any attempt to suppress or undermine the right of citizens to question, is likely to be resisted in such a world. The same is strenuously, even violently resisted, in a developing world that has just undergone a transition from colonial dictatorship. In other words, the utterances are made within a prescribed (national) framework although individuals usually seek to convey a potentially divisive and undemocratic message.

The content of the utterances must be evaluated in terms of whether they couch a language that equates the present situation- good or bad, with the wishes of those who have ascended to the spiritual world (legitimation). In other words, the rhetoric used must be scrutinised to see whether it is not an attempt to 'rewrite' popular biblical texts in support of the ideological goals of politicians. The intention is not to pass a value judgement but to understand what, how and why? It is not my place to decide on the correctness or otherwise of the utterances- a task which, according to Voloshinov's scheme, resorts with the 'evaluative context'. Nor do I intend to deny individual politicians of their right to use the scriptures as they understand them. The difference is that whatever their intentions-pure or impure, tend to become systemic, a risky situation as seen in the cases of Nazi Germany, Apartheid South Africa and Bush's United States of America.

It is a moot point whether a politician can utter a neutral statement or use a text that is not in aid of their ideological goals. This question is not raised from a political or psychological angle but more from the perspective of a hermeneutic of suspicion. Therefore, no attempt to get into the mind of the protagonist will take place. Instead, the intentions will be inferred from the context in which the utterances are made. What could be said without contradiction is that the individuals chosen as examples are now located within the ruling class, regardless of their initial class origins. Our answer is therefore, that for as long as the utterances are made publicly, it must be presumed that they are ideologically loaded in the sense of party-politics. Otherwise they are of no use to the politician.

The second issue pertains to the kind of texts that resonate with the politicians's ideological goals. Sociology of knowledge would tell us that knowledge production is classspecific. Members of the bourgeoisie class do not, for example, see the same thing in the same way as working class members, in a biblical text. Their outcomes are therefore also not the same. The choice of texts also differs because they appeal differently to each group. Politicians who by the nature of their work and social status have joined the ruling class, target texts that take them back to the audiences they wish to'reconvert' to their way of seeing reality. The difference here is that they appear to be speaking the same language while they are giving their own interpretations (rewrite) of the text. Anyone who has been on a moving train as it changes lines will understand the smoothness of this transition better. This is the effect calculated words have on the target audience.

It is the contention of this article that the problem manifests in two ways, namely, embeddedness in certain forms of religious expressions and direct political speeches and/or pronouncements. West (2012) aptly categorises such religious expressions as those with a focus on individual morality rather than the 'common good' and, if I may add, emphasising personal sins and guilt while the state is left on its own (Draper 1988).

Context and the intentions of politicians who use the texts seem to be inseparable. There is a purposeful use of the scriptures, aimed at a target audience (see for example, piety and subversion in Johnny Cash's Man in White where Twomey [2015:12] notes that there is an attempt to rewrite the text as the 'Man in Black' confronts the prevalent culture). Althusser's respective points on language and legitimation are of cardinal importance in understanding this. Language creates the impression of consciousness about the realities surrounding one while legitimation establishes a link between the present and the past, reinforcing the idea that the present is a fulfilment of the dreams of past generations. ${ }^{15}$ Post-revolution Russia, as pointed out by Zizek, used the same tactics against those who raised questions about the official programmes.

We however see in the context of the Roman Empire that individuals in positions of power concretised the reality they projected. For example, those elected in positions of power became benefactors to the extent that they provided for the communities that elected them by building roads, aqueducts and stadia (Van Eck 1998; Speckman 2002). Some Roman Emperors, (for example, Augustus, Cicero) not only declared themselves gods. They also provided for the city as a god would have provided. In so doing, they were declaring that their actions were in continuity with those of the ancestors who live in a spiritual world or that they were sanctioned from 'above' (legitimation).

The use of the Bible to justify commercial and political interests of those who wished to perpetuate the practice of slavery in the United States of America and those who agreed with Hitler's creation of an Aryan race in Germany have already been alluded to. In recent history, the respective utterances of Bush and Obama have called for attention. Their utterances are documented in a number of major and minor publications ${ }^{16}$ and in the interest of preserving space,

15.In his explanation of the intention of the author of Acts, Esler (1998) uses the concept of legitimation to explain that the author seeks to reassure the audience that their preference of the new movement over Judaism is approved in a spiritual world towards which they are striving. This echoes the sentiments of Berger and Luckmann's (1977) 'creation of a symbolic universe'.

16.For example, God wants to erase Middle-East enemies before the new age begins (GQ Magazine 24 May 2009); Statement on President or Preacher George W. Bush's use of religious language (Interfaith Alliance 11 February 2003); With God on our side: Religion in George W Bush's foreign policy speeches, A.E Black, Wheaton side: Religion in George W Bush's foreign policy speeches, A.E Black, Wheaton College (September 2004); Bring it on: the apocalypse of George
International. (Australia Inc. Culture Policy 13 November 2004). 
they will not be pursued in any detail here. Suffice it to mention the line used to seal their respective speeches: 'God bless the United States of America' which might mean different things to different audiences. Given Bush's behaviour while in office, he may have been understood to be in line with one of his predecessor's attempt to portray America as a chosen nation. Based on Obama's behaviour in office, his may have been seen by a different audience, as being in continuity with Martin Luther King's American Dream (1963). Clearly, Bush and Obama are on different sides of the political line. It should therefore be expected that they will use the Bible for different ideological purposes.

The pattern that is described above replays itself over and over in the South African history. In the documents of the Dutch Reformed Church as analysed in Loubser's book (1987) the use of scriptures to justify Apartheid is disturbing but understandable from a hermeneutical perspective. Selected biblical texts are read within the context of a newfound nationalism (Afrikaner nationalism, starting with the formation of Afrikaner Broederbond in 1918) and on the eve of Afrikaner independence (Welsh 2009:13-18). The interpretative methods applied may have appeared neutral to those who knew no better. After all, the interpreter used his privilege to see what according to one of Gadamer's disciples, Severino Croatto (1983:144), 'the text allows him to see'. The task of the exegete was to interpret the 'will of the gods' and some theologians of the Volk (nation) would claim to have done exactly that in respect of the 'Afrikaner gods'.

On what grounds other than the moral ones could their interpretations be faulted? If the text was vulnerable, then they used its malleability to bolster their political ends, namely, the quest for an independent white republic within Africa to the exclusion of the indigenous Africans. This became a theological and ethical dilemma until the bold step of declaring Apartheid a heresy in 1982 and a final confirmation of the same by the general synod of the Dutch Reformed Church in 1998. A careful selection and, in the sense discussed above, rewriting of certain biblical texts - from Genesis, Exodus, Deuteronomy, Joshua, the Acts of the Apostles, 1 Corinthians, parts of the letter to the Galatians and the Book of Revelation - supports this (Loubser 1997). Common among these was the theme of separateness in various shades and packages (e.g. racial, linguistic, cultural, national).

Against this backdrop, the second manifestation of the problem, the use of scriptures in political speeches and/or pronouncements, must be viewed. The motives may be different. As West (2012) correctly observes, Mbeki uses the scriptures to 'fight corruption'. Hence he goes into great lengths to analyse the passage so as to bring it closer to his audience which would obviously be characterised by a high level of sophistication while Zuma plays with catch-words and phrases which he repeats over and over, with the desired effect.

The ideological undertones may not be obvious in Mbeki's writings and speeches as he is focusing on what West refers to as 'guiding the nation towards an RDP of the soul' (2012:112), that is, working within the framework of a preapproved African National Congress (ANC) document. However, like any other shrewd politician, he knew his target very well and chose an appropriate language for it. In this case, it is the middle class who had a lot to lose from corruption while some of them, owing to petty bourgeoisie aspirations, were prone to it. He did not do so like any other lay person would have done but seriously engaged the text, employing excellent linguistic and analytical skills. The texts covered in his speeches are drawn inter alia, from such popular texts as Proverbs and the Gospels. What distinguishes his use of the scriptures from that of Zuma which I consider below is the overt pastoral concern which West characterises as 'guiding the nation'. There is an ethical thrust which shifts focus away from individual and organisational interests to correct behaviour. West thus provides a spot-on analysis of Mbeki's use of biblical texts and his own justification for doing so although we could take issue with him for concluding that 'the resources Mbeki has invested in the text signify a return of religion to the public realm' (West 2012:122). ${ }^{17}$ This much about Mbeki should suffice for the purposes of this article.

With Bush, Mbeki and Obama out of the way, we now turn to Jacob Zuma whose 'contaminated' use of the scriptures is not so obvious while it appears to be reckless. I agree with van Onselen (2014::xii) albeit for a different reason, that Zuma is often misunderstood. His manner of doing and saying things is, in my view, largely responsible for the misunderstanding. Yet it is this which he exploits in conveying his ideology. $\mathrm{He}$ does so consciously and optimally. In my view, the words he utters are at times calculated, at times not but they still have the desired effect, precisely because they are aimed at a target audience, with a purpose. As such, he is not speaking for himself but with the blessing of those who surround him, the ideological beneficiaries. Assuming that this is the case, ideology cannot be divorced from the manner in which Zuma talks and behaves precisely because of the impact his utterances have on social consciousness.

The list of original utterances provided by van Onselen (2014:3-18) as well as those provided by West (2010:51-63) indicate no attempt to exegete or interpret any text in the manner we understand interpretation. However, the religious symbolism used, such as him being 'like a black Jesus' (2006) or 'ruling until Jesus comes' (2008) or the angels in heaven wearing 'green, black and gold' (2011), a verse from the epistles 'support for the ANC is an unequivocal biblical declaration that if God is for us, who can be against us'(2009) and many more carefully chosen texts and symbols. Their repetition, for example, the promise of heavenly benefits for those who carry ANC membership cards (van Onselen ibid. p.11) are meant to reinforce something. In the scriptures, it is only Jesus who

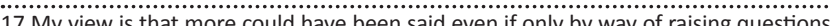
For instance if the could have been said even if . dismissal of Zuma from his cabinet post in 2005 , would his use of scriptures not be ideologically motivated? Why would anyone believe the sudden relationship with the Bible? Did his pan-Africanist ideology play any role in his eagerness to polish up the African image and perception? It would be naïve of us not to raise such questions. 
promises heavenly benefits. As stated above, my intention in this article is to look at 'what, why and how', not to analyse individual texts. Below, we shall see the correlation between these and the attempt to legitimate Zuma and the ANC. More importantly, it will become clear why the South African Communist Party (SACP) for example, prefers to piggy-back on him in particular though it may be at odds with the ANC on various policy issues. Those who focus on what appears to be glibness in the manner he expresses things fall short of seeing the implications of his actions.

Starting with West's analysis, I want to go on to substantiate the above averments. West $(2012: 141)$ seems to agree with his conversation partner at the carwash that Zuma knows the Bible more than Mbeki does. However, this is based on the understanding that Zuma brought religion to the public sphere - two different issues in my opinion. Mbeki, as West has shown, worked with specific texts and engaged them thoroughly while Zuma consciously uttered words (with which everyday Bible users can identify) that grounded the present in the past (e.g. invoking the names of Qamata and those of departed ANC leaders). Some utterances on the list provided by Van Onselen relate to the general religious jargon while others are based on biblical texts. Given the fact that Zuma works mostly with the working class and rural audiences, it is not necessary for him to attempt an analysis of the text although he prepared texts for his addresses at the Rhema Church fellowships. The words themselves, as they are taken directly from the Bible and their literal meaning are enough to stir up an individual's spiritually.

A display of the power this evokes was seen during the hearing of the Review Application of the Democratic Alliance (2014) pertaining to the withdrawal of charges against Zuma by a former head of the National Prosecutions Authority. Leaders of Pentecostal churches, mobilised by a Pastor Zondi, were there to pledge solidarity with Zuma. They went to the extent of laying hands on him. The same happened when the Democratic Alliance took up the Public Protector's recommendations that the South African Broadcasting Cooperation should discipline the Central Operations Officer (COO) of the Broadcasting Corporation for falsifying his qualifications (2014). Leaders of the same churches marched to the Public Protector's Office and accused her of 'working against God's will'. The COO, known to be Zuma's close associate, was also subsequently 'ordained' pastor by the leadership of the same family of churches. The idea is to force the office of the Public Protector to 'defer to the language of authorities'.

The above reveals the extent to which an ideological usage of the Bible and symbolism arising from it can be effective. Zuma had before then invoked the spirits of Luthuli, Rubusana, Plaatjie, Calata, Tambo, Mandela and other deceased leaders of the ANC, in legitimating his current actions. In addition to that, he has invoked the name of Jesus and passages that are used for Christological purposes, thus putting himself alongside Jesus. In fact, his being expelled from the cabinet after the verdict on the Shabir Schaik trial (2005), the rape case he was charged with (2007) and the charges of corruption that were being investigated against him were all used as manifestations of the alleged conspiracy and persecution which were similar to the experience of Jesus Christ (Van Onselen 2014:14).

He lacks in rhetorical skills while he is excellent at connecting with popular language. On its own, this has a limited ideological impact. Two things take the ideological dimension further though. These are the carefully selected utterances and his personal community projects ${ }^{18}$ which portray him as a 'Plenipotentiary' of the gods or a messiah among the rural, poor and lowly people. When all this is combined with the link of his mandate to the spirits beyond this world, anyone questioning it is in fact, seen to be opposing the 'will of the ancestors of democracy' (see SACP various media statements between 2007 and 2015 as well).

In support of my view on this, I advance the threats to the judiciary in South Africa (Lewis 2008; Warikandwa 2012, http:/ / allafrica.com/stories/201203231050.html; Calland 2015), ongoing threats towards academics and organic intellectuals (Star, 10 July 2015), threats to the media (Press Bill and media statements by the SACP-Secretary General) and attempts to undermine other state institutions that have a constitutional obligation to scrutinise actions of the state organs and its officials (Media statements in respect of Public Protector's office). When Zuma's words are uttered against the kind of background that has just been outlined, the ideological puzzle gets complete. Apartheid was a system undergirded by racial philosophy. Is the present administration a democracy from a Leninist perspective, relying on the scriptures and other religious symbols as apparatuses for a 'dialogic interaction'? The 'evaluative context', that is, the South African public, should decide.

\section{Conclusion}

I have started off by raising questions pertaining to 'why' and 'which' scriptural verses are being used by politicians. I also briefly looked at how they were (ab)used in the South African context before and after democracy. Whatever I have found in response to these questions is only tentative as I am observing the developing situation in respect of South Africa closely. This is because I am wrestling with further questions pertaining for example, to why Hitler succeed in doing what he was doing in the name of religion and nationalism and why the end result was not timeously foreseen. I am also asking why the Apartheid theology and system were allowed to exist for three decades before questions which eventually led to its being declared a heresy were raised by theologians. Something tells me that our modesty (biblical scholars) in asserting the principles of our trade tends to leave us in the position of flame - dowsing or wind-chasing (which is more challenging).

18.Inter alia, J.G. Zuma Education Trust, Masibambisane Rural Development Trust, Schools Chess, Annual Youth Marathon. 
Perhaps in Mbeki and Obama, we have rhetorical devices employed in the initial sense of persuasion while in Augustus, Cicero, Bush and Zuma, we have ideology at work, clothed in religious language and landing as missiles on unsuspecting communities. It is up to the Biblical Studies communities to scrutinise these. In the cursory ideology critique I have conducted, I have found support in the manner in which the scriptures are being used, which legitimates the actions of the present incumbent and his administration, the personal projects that further entrench him as the 'chosen one' and the public statements of the SACP as well as the programmes it promotes. While no value judgement is being passed on this, the exercise was intended to lay the situation bare so as to enable the public to make its choices. On my part as a biblical scholar, my verdict is that the manipulation of the texts for ideological purposes is tantamount to their subversion.

\section{Acknowledgements Competing interests}

The author declares that he has no financial or personal relationships which may have inappropriately influenced him in writing this article.

\section{References}

Althusser, L., 1984, Essays on Ideology, Thetford Press, Norfolk.

Althusser, L., 2001, Lenin and Philosophy and other essays, Monthly Review, New York. Bauckham, R., 1989, The Bible in Politics: how to read the Bible Politically, John Knox, Westminster.

Benedix, C.H., Subverting scriptures: critical reflection on the use of the scriptures, Macmillam, Palgrave.

Berger, P. \& Luckman, T., 1976, Social construction of reality: a treatise in the sociology of knowledge. Penguin, Hammondsworth.

Berlinerblau, J., 2008, Thumpin' It: The use and Abuse of the Bible in today's presidential politics, John Knox, Louisville/London/Westminster.

Bygrave, S. 1993, Kenneth Burke: Rhetoric and Ideology, Routledge, London.

Croatto, S.J., 1987, Biblical hermeneutics: Toward a theory of reading as the production of meaning, Orbis, Maryknoll.

Draper, J.A., 1988, 'Humble submission to Almighty God and its biblical foundation: Contextual exegesis of Romans 13:1-7', Journal of Theology for Southern Africa 63, 30-38.

Esler, P., 1987, Community and gospel in Luke-Acts, Fortress, Minneapolis.

Frey, C., 1994, 'The biblical tradition in the perspective of political theology and political ethics' in eds HG Reventlow, et al Politics and Theopolitics in the Bible and postbiblical literature, JSOT Press, Sheffield.

Gardiner, M., 1992, The dialogics of critique: MM Bakhtin and the theory of ideology, Routledge, New York.

Gillingham, S.E., 1998, One Bible, many voices: Different approaches to biblical studies. SPCK, London.
Gottwald, N., 2008, In the Shadow of the Empire: Reclaiming the Bible as a history of faithful resistance, R. Horsley (ed.), John Knox, R Westminster.

Gunda, M.R, \& Kugler, J. (eds), 2012, The Bible and politics in Africa, Bamberg University Press (E-book).

Hall, S., 1986 'The problem of ideology: Marxism without guarantees', Journal of Communication Inquiry10(2), 28-44.

Horsley, R. (ed.), 2008, In the Shadow of the Empire: Reclaiming the Bible as a history of faithful resistance, John Knox, Westminster.

Isaak, P., 1990, 'Church and development in the context of reconciliation and nationbuilding: the Namibian experience' in R. Koegelenberg (ed.), Church and development: an interdisciplinary approach, Ecumenical Foundation of South development: an inter
Africa, Stellenbosch.

Lacey, W.K. (ed), 1986, Cicero: Second Phillipic Oration, ARIS \& Phillips, England.

Loubser, J.A., 1987, The apartheid Bible: A critical review of racial theology in South Africa, Maskew Miller Longman, Cape Town.

Maluleke, T.S. 2002, 'Of Collapsible Coffins and Ways of Dying: the search for Catholic contextuality in African perspective', Ecumenical Review 54(1), 313-332.

McLennan, G., Molina, V. \& Peters, R., 1977, Althusser's theory of ideology, Centre for Cultural Studies, Routledge, New York.

Metzger, B., 1987, The canon of the New Testament: Its origin, development and significance, Clarendon Press, Oxford.

Mollett, M., 2010, 'Creeping Crusade', PhD Thesis, Dept. of Biblical Studies, University of South Africa.

Mosala, I.J., 1991, 'Bible and liberation in South Africa in the 1980s: Toward an antipopulist reading of the Bible' in D. Jobbling (ed.), The Bible and the politics of exegesis, Pilgrim, Cleveland.

Mosala, I.J., 1989, A black biblical hermeneutics of liberation in South Africa, David Philip, Cape Town.

Nkrumah, K., 1957, Inaugural speech, 6 March, Ghana.

Nzimande, BE 2015, The Star, 10 July.

Speckman, M.T., 2002, “"Bread and Circuses": Obligations of a public figure to his/her social constituency', Acta Patristica et Byzantina 13(1), 187-206

Speckman, M.T., 1995, Bible study method, presentation at the ISB and Worker Ministry Workshop, July, Pietermaritzburg.

Suggit, J.N., 1994, The word of God and the people of God: Relationship between the Bible and the church, Celebration of Faith, Fish Hoek.

Turner, E.A., 1996, 'Irony as ideology critique in Deutero-Isaiah with special reference to the parody on idolatry', Annals. University of Stellenbosch, vol. 2, pp. 1-53.

Tutu, D., 1979, 'African and Black Theologies: Soul mates or antagonists?' in J.H. Cone \& G.S. Wilmore (eds.), Black Theology: A documentary history, 1966-1979, pp. 483-491.

Van Onselen, G., 2014, Clever Blacks, Jesus and Nkandla. The real Jacob Zuma in his words, Jonathan Ball Publishers, Johannesburg/Cape Town.

Vengeyi , O., 2012, 'The Bible in the service of Pan-Africanism: The case of Dr Tafataona Mahoso's Pan-Africanism. Biblical Exegesis' in M.R. Gunda \& J. Kugler (eds.), The Bible and politics in Africa, Bamberg University Press [E-book].

Voloshinov, V., 1973, Marxism and the philosophy of language, Harvard University Press and Academic Press Inc., Cambridge.

Welsh, D., 2009, The rise and fall of Apartheid, Jonathan Ball, Johannesburg.

West, G.O. 2012, 'The ANC's deployment of religion in nation building: From Mbeki to the "RDP of the soul", to Jacob Zuma' in M.R. Gunda \& J. Kugler (eds.), The Bible and politics in Africa. Bamberg University Press [E-book].

West, G.O., 2010, 'Jesus, Jacob Zuma, and the New Jerusalem: Religion in the public realm between Polokwane and the Presidency', Journal of the Study of Religion 23(1\&2), 43-70.

West, G.O., 1994, 'Constructing critical and contextual readings with ordinary readers: Mark 5:21-6:1', paper read at the New Testament Society of South Africa Congress, Stoney Ridge Farm, Hekpoort, 28-31 March 1994.

Wittenberg, G., 1993, Prophesy and protest, Cluster Publications, Pietermaritzburg.

Zizek, S., 1994, Tarrying with the Negative: Kant, Hegel, and the Critique of ideology, Duke University Press, Durham. 